\title{
CAJA DE CARTÓN O EL PARTO DE UN PÁJARO
}

podría decir que apenas

hace unos días apenas

conocí el mundo

como recién nacido de una caja de cartón

salió volando un mundo pájaro

se detuvo en mi frente y desde ahí

comenzó a hablar dijo:

pensé en su baba

pensé en un barco

pensé en un muelle

pensé que solo conozco mi frente pensé que

mi frente no es lo único que los demás conocen de mí

desde ahí el pájaro-pájaro pensó:

mi mente podría

ser el mundo recién nacido

en otros hábitos

de la materia

desde ahí el mundo-mundo pensó:

tal vez habría podido decirle:

esa estrella tiene nombre

(pero por qué

nombramos las estrellas

por qué esa insistencia en

nombrar

tocar con

las palabras las cosas)

(las estrellas tienen nombres

no me interesan

los nombres de las estrellas 
puedo verlas

puedo señalarlas con la punta de la lengua sin decir)

nuestros cuerpos son tan blandos

que

acostados en el suelo podríamos jurar

que

no son el mismo mundo

que

el mundo del cuerpo

el mundo de la baba

el mundo del suelo

son mundos que no se conocen

quizá solamente

si escupimos en el suelo

esos mundos lleguen a conocerse

escupamos en el suelo

pensar en:

un barco

pensar en:

un muelle

es una forma

de habitar la indecisión

una forma de no saber si movernos o

quedarnos quietos

como si

(el parto de un pájaro

el parto de un mundo)

una caja de cartón 